\title{
PENURUNAN PEREKONOMIAN MASYARAKAT SOLOK AKIBAT DAMPAK DARI PANDEMI COVID 19
}

\section{ILJASMADI,, ZURAEDAH INDAH, BUDI HARTO}

\begin{abstract}
This study aims to explore the impact of the COVID-19 pandemic on the welfare of the people in Solok. Primary data came from 36 respondents from six sub-districts in Solok from different professions and were affected by the pandemic as well as in-depth interviews with the heads of puskesmas, sub-districts and representatives of $R T$ heads. Respondents' income experienced a sharp decline between 30\%-70\% at the beginning of the pandemic while expenses tended to remain constant. This condition causes respondents to have to deal with family expenses. In general, there was a decrease in the income level of respondents during the pandemic, but not all respondents made drastic changes in food patterns. They only replace certain types of side dishes and prefer to find other sources of income to maintain the old spending patterns rather than changing family spending patterns.
\end{abstract}

Keywords: Covid-19 pandemic, economic impact, changes in consumer patterns.

\begin{abstract}
Abstrak: Studi ini bertujuan untuk mengeksplorasi dampak pandemic covid-19 terhadap kesejahteraan masyarakat di Solok. Data primer berasal dari 36 responden dari enam kecamatan di Solok dari profesi yang berbeda dan terdampak pandemic serta wawancara mendalam kepada kepala puskesmas, camat dan perwakilan ketua RT. Pendapatan responden mengalami penurunan tajam antara 30\%-70\% di awal masa pandemic sementara pengeluaran cenderung tetap. Kondisi ini menyebabkan responden harus mensiasati pengeluaran keluarga. Secara umum memang terjadi penurunan tingkat pendapatan responden selama masa pandemic, namun tidak semua responden melakukan perubahan pola pangan secara drastis. Mereka hanya mengganti jenis lauk tertentu dan lebih memilih mencari sumber pendapatan lain untuk mempertahankan pola pengeluaran yang lama daripada merubah pola pengeluaran keluarga.
\end{abstract}

Kata kunci: Pandemi covid-19, dampak ekonomi, perubahan pola konsumen.

\section{A. Pendahuluan}

Covid-19 atau yang lebih dikenal sebagai Virus Corona telah menjadi perhatian publik sejak kemunculannya terdeteksi di Tiongkok untuk kali pertama di awal tahun 2020. Meninggalnya ribuan jiwa akibat virus ini membuatnya menjadi pusat perhatian banyak negara, termasuk Indonesia. Pandemi COVID-19 terbukti telah memberikan tekanan pada kondisi ekonomi dan sosial di Indonesia sejak akhir tahun 2019. Dampak ekonomi ini berdampak luas di seluruh wilayah Indonesia. Perekonomian masing-masing daerah terancam, ditambah dengan kondisi daerah yang lebih buruk dari sebelumnya. Karena hal tersebut, pemerintah Indonesia langsung mengambil langkah agresif agar angka penyebaran bisa ditekan semaksimal mungkin.

Indonesia lebih memilih pembatasan sosial (social distancing) sebagai solusi daripada melakukan lockdown yaitu mengunci akses masuk dan keluar wilayah bagi siapapun untuk mencegah penyebaran virus yang umumnya digunakan oleh kebanyakan negara. Inti dari pembatasan sosial adalah menjauhi diri dari aktivitas sosial secara langsung dengan orang lain, sedangkan lockdown berarti suatu wilayah akan diisolasi dan terjadi pemberhentian total semua aktivitas di wilayah tersebut. Alasan fundamental kenapa Indonesia lebih memilih memberlakukan pembatasan sosial adalah banyak masyarakat Indonesia yang mengandalkan upah harian, jadi akan rawan mereka tidak bisa mencari mata pencaharian apabila lockdown diberlakukan. Menjaga jarak sosial setidaknya memberlakukan beberapa himbauan kepada seluruh warga negara, diantaranya adalah bekerja dari rumah, belajar dari rumah, dan beribadah di rumah.

Karena Indonesia adalah negara berkembang, maka masalah kemiskinan merupakan masalah yang penting dan pokok dalam upaya pembangunannya. Keberagaman pandangan 316 Lembaga Penelitian dan Penerbitan Hasil Penelitian Ensiklopedia $\quad$ E-ISSN: 2657-0300 
tentang kemiskinan menunjukan bahwa kemiskinan merupakan fenomena multi dimensi. Fenomena ini membuat pengukuran kemiskinan menjadi tidak mudah. Namun demikian, kemiskinan tetap harus diukur sebagai gambaran dan bahan pengambilan kebijakan penanggulangan kemiskinan. World Bank Institute (2020) mengemukakan empat alasan kemiskinan harus diukur, yaitu (1) agar orang miskin terus berada dalam agenda dan diperhatikan, (2) pengidentifikasian orang miskin dan keperluan intervensi mengenai pengentasan kemiskinan, (3) pemantauan dan evaluasi proyek atau kebijakan intervensi terhadap orang miskin, dan (4) evaluasi efektivitas lembaga-lembaga pemerintah dalam pengentasan kemiskinan. Angka kemiskinan memiliki pengaruh signifikan positif terhadap total kasus COVID-19. Salah satu alasan hal ini terjadi adalah bahwa individu dan populasi miskin tidak memiliki akses ke layanan kesehatan dan mungkin mendapat informasi yang salah dan miskomunikasi karena kurangnya akses ke saluran informasi, sehingga, mereka lebih cenderung mengabaikan peringatan kesehatan masyarakat (Ahmed, Ahmed, Pissarides, \& Stiglitz, 2020). Penelitian sebelumnya oleh (Patel et al., 2020) menyatakan beberapa alasan utama seperti akomodasi yang terlalu padat, akses terbatas ke ruang luar pribadi, pekerjaan yang tidak fleksibel, dan kondisi kerja yang tidak stabil menjadi faktor yang meningkatkan paparan COVID-19 pada populasi miskin.

Selama periode 2017 hingga 2020, jumlah penduduk miskin Solok berfluktuasi dari sebesar 30,93 ribu jiwa Pada tahun 2017, meningkat selama dua tahun berturut-turut hingga di Tahun 2018 jumlah penduduk miskin tercatat sebanyak 34,11 ribu jiwa, namun tiga tahun terakhir sejak tahun 2017 jumlahnya terus mengalami penurunan hingga di tahun 2019 menjadi 31,46 persen atau 4,88 persen dari jumlah penduduk, atau dapat dikatakan juga bahwa terdapat 4,88 persen penduduk Solok yang hidup dibawah garis kemiskinan. Garis kemiskinan adalah garis batas yang membedakan antara kelompok penduduk miskin dan tidak miskin. Garis ini menunjukkan sejumlah rupiah yang diperlukan oleh individu untuk dapat memenuhi kebutuhan hidup minimumnya, baik kebutuhan makanan maupun non makanan. Penduduk dengan nilai pengeluaran di bawah garis kemiskinan akan dikategorikan sebagai penduduk miskin. Sebaliknya penduduk dengan jumlah pengeluaran yang lebih besar dari nilai garis kemiskinan dikategorikan sebagai bukan penduduk miskin. Garis Kemiskinan Solok pada tahun 2014, tercatat 369.079 rupiah per kapita per bulan (Gambar 2) Angka tersebut menunjukkan bahwa seseorang di Solok akan dikategorikan sebagai penduduk miskin jika total pengeluaran untuk konsumsi makanan dan non makanan setiap bulannya kurang dari 369.079 rupiah. Garis Kemiskinan pada tahun 2015 mencapai 403.905 rupiah per kapita per bulan dan terus mengalami peningkatan untuk tahun selanjutnya. Pada tahun 2019 garis kemiskinan tercatat 523.726 rupiah perkapita per bulan. Secara rata-rata laju peningkatan garis kemiskinan selama tahun 2014-2019 adalah sebesar 7 persen per tahun.

Berdasarkan data dari Dinas Kesehatan Solok bulan November 2020 (Tabel 1) di Solok terdapat 2195 kasus kontak erat, 724 kasus suspek dan 644 positif COVID-19. Yang dimaksud dengan kasus suspek adalah seseorang yang memiliki salah satu dari kriteria berikut: a) Orang dengan Infeksi Saluran Pernapasan Akut (ISPA) dan pada 14 hari terakhir sebelum timbul gejala memiliki riwayat perjalanan atau tinggal di negara/wilayah Indonesia yang melaporkan transmisi local; b) Orang dengan salah satu gejala/tanda ISPA. ada 14 hari terakhir sebelum timbul gejala memiliki riwayat kontak dengan kasus confirmasi/probable COVID-19; c) Orang dengan ISPA berat/pneumonia berat yang membutuhkan perawatan di rumah sakit dan tidak ada penyebab lain berdasarkan gambaran klinis yang meyakinkan.

Yang dimaksud dengan kontak erat adalah Orang yang memiliki riwayat kontak dengan kasus probable atau konfirmasi COVID-19. Riwayat kontak yang dimaksud antara lain: a) Kontak tatap muka/berdekatan dengan kasus probable atau kasus konfirmasi dalam radius 1 meter dan dalam jangka waktu 15 menit atau lebih.: b)Sentuhan fisik langsung dengan kasus probable atau konfirmasi) (seperti bersalaman, berpegangan tangan, dan lain-lain); c) Orang yang memberikan perawatan langsung terhadap kasus probable atau konfirmasi tanpa menggunakan APD yang sesuai standar; d) Situasi lainnya yang mengindikasikan adanya 
kontak berdasarkan penilaian risiko lokal yang ditetapkan oleh tim penyelidikan epidemiologi setempat.

Kepadatan penduduk juga berpengaruh dengan prevalensi kasus COVID-19, dalam hal ini diukur dari jumlah kasus. Kepadatan penduduk berperan penting dalam pertumbuhan COVID-19 karena sebanding dengan laju kontak (Rocklöv \& Sjödin, 2020). Studi sebelumnya dari tahun 2020 di Iran menggunakan fungsi Partial Correlation Coefficient (PCC) dan SobolJansen menegaskan bahwa kepadatan penduduk memiliki hubungan langsung dengan wabah COVID-19 (Ahmadi, Sharifi, Dorosti, Jafarzadeh Ghoushchi, \& Ghanbari, 2020).Kepadatan penduduk perkotaan memberikan peluan lebih besar dalam penyebaran covid-19 jika tidak dilakukan pembatasan sosial. Solok merupakan wilayah dengan tingkap kepadatan penduduk tertinggi di Sumbar memiliki resiko lebih tinggi terhadap penyebaran virus Covid 19 ini.

Pandemik covid-19 diprediksi akan memberikan dampak luar biasa pada sektor-sektor seperti kinerja perdagangan, nilai tukar, aktivitas bisnis akan mengalami penurunan drastis. Dampak pandemic COVID-19 menyebabkan berkurangnya pasokan tenaga kerja, pengangguran, berkurangnya penghasilan, meningkatnya biaya melakukan bisnis di setiap sektor (termasuk gangguan jaringan produksi di setiap sektor), pengurangan konsumsi karena pergeseran preferensi konsumen atas setiap barang, kerentanan masyarakat terhadap penyakit serta kerentanan terhadap perubahan kondisi ekonomi.

Pembatasan sosial yang diberlakukan oleh pemerintah menyebabkan seluruh masyarakat terkena dampak, terutama masyarakat golongan pendapatan menengah ke bawah dan pekerja harian. Kelompok masyarakat yang sebelumnya tidak termasuk miskin akhirnya menjadi miskin karena pembatasan berskala luas ini. Kemiskinan perkotaan relatif lebih tinggi daripada kemiskinan pedesaan termasuk Solok. Persentase kemiskinan Solok adalah 4,88 persen, menurun dibanding tahun sebelumnya 2018. Kondisi ini adalah yang terendah dari periode lima tahun terakhir dengan jumlah 31,46 ribu penduduk miskin. Pembatasan sosial yang diberlakukan oleh pemerintah Solok menyebabkan seluruh masyarakat terkena dampak, terutama masyarakat golongan pendapatan menengah ke bawah dan pekerja harian. Berdasarkan latar belakang tersebut maka studi ini bermaksud untuk mengeksplorasi dampak ekonomi pandemic covid terhadap kesejahteraan masyarakat Solok serta bagaimana pola konsumsi rumah tangga pada masa pandemic covid.

\section{B. Metodologi Penelitian}

Bentuk penelitian ini adalah penelitian yang yang menggunakan analisa deskriptif dan eksploratif. Studi ini menggunakan analisis deskriptif ini sebagai alat analisa yang bertujuan untuk menganalisis keadaan masyarakat Solok saat pandemic Covid-19. Lokasi penelitian ini dilaksanakan di enam kecamatan yang ada di Solok yaitu kecamatan Kubung. Kecamatan Kubung, kecamatan X Koto Diatas, kecamatan Sungai Lasi, kecamatan Bukit Sundi dan Kecamatan Singkarak. Solok dijadikan sebagai lokasi penelitian karena merupakan wilayah dengan tingkat kepadatan tertinggi dan tingkat kemiskinan tertinggi di Sungai Lasi, sehingga pembatasan sosial akan berdampak luas bagi masyarakat dan pandemic covid-19 memerikan dampak luas bagi masyarakatnya. Studi ini menggunakan data primer yang diperoleh dan dikumpulkan sendiri untuk mendapatkan informasi-informasi yang dibutuhkan. Metode pengumpulan data dengan menggunakan kuesioner, hasil observasi dan wawancara mendalam. Kuesioner digunakan sebagai pedoman wawancara bagi responden Kuesioner dan wawancara ditujukan untuk responden yang menjadi sampel. Populasi yang digunakan adalah seluruh masyarakat Solok . Sampel teridi dari enam responden dari enam kecamatan yang ada di Solok sehingga total responden adalah tigapuluh enam responden. Teknik sampel menggunakan teknik purposive sampling dengan menetapkan ciri-ciri khusus yang sesuai kebutuhan.

\section{Hasil dan Pembahasan}

Sebuah studi oleh Esubalew A. (2006) tentang faktor-faktor penentu kemiskinan perkotaan di salah satu kota di wilayah Amhara, Debre Markos, menemukan bahwa 
pendapatan bulanan rata- rata, ukuran keluarga, tingkat pendidikan dan insiden penyakit sebagai penentu signifikan kemiskinan perkotaan. Meskipun semua kelas masyarakat dapat terkena dampak yang sama oleh pandemi ini, masyarakat yang terpinggirkan, terutama masyarakat miskin perkotaan, pekerja lepas, pekerja sementara dan informal telah terkena dampak pandemi secara tidak proporsional. Imobilitas pekerja dari kota satelit dan ketidakmampuan mereka untuk membayar perawatan kesehatan, ditambah dengan situasi yang memaksa mereka untuk tidak datang bekerja membuat mereka lebih rentan terhadap pandemi (McKibbin \& Fernando, 2020).

Responden dalam penelitian ini berjumlah 36 orang yang berasal dari enam kecamatan di Solok. Rentang uimur responden sebagian besar berada pada usia produktif, paling banyak pada kelompok umur 35 - 45 tahun sebanyak $50 \%$. Jika dilihat dari komposisi umur, dapat disimpulkan bahwa responden merupakan pasangan muda dengan jumlah tanggungan paling banyak 3-4 orang $(50 \%$. Status responden hampir semuanya adalah kepala rumah tangga (suami) dan hanya $10 \%$ yang berstatus sebagai isteri. Responden yang berstatus sebagai isteri menyatakan bahwa alasan mereka ikut mencari nafkah adalah bertujuan untuk membantu meringankan beban ekonomi suami, terutama di masa pandemic karena ada suami responden yang tidak lagi bekerja di masa pandemik.

Dinamika kemiskinan terkait erat dengan karakteristik demografi rumah tangga terutama ukuran keluarga, rasio ketergantungan, jenis kelamin kepala rumah tangga, komposisi umur dan melek huruf dari kepala rumah tangga. Ukuran rumah tangga adalah faktor utama demografi dan umumnya berhubungan positif dengan status kemiskinan (Qureshi dan Arif , 2001; Chaudhry, 2009). Ukuran keluarga besar kemungkinan akan membebani aset dan sumber daya rumah tangga tambahan (McKay dan Lawson, 2002). Tercatat 53\% responden berpendidikan SMP dan SD dan hanya $8 \%$ responden berpendidikan diploma. Bila dikaitkan kondisi pendidikan terakhir responden dengan jenis pekerjaan terlihat relevansinya .Jenis pekerjaan responden mulai dari sopir, pengemudi ojek on line, pedagang makanan, jasa salon, penjual masker, juru parkir, penjahit, penjual koran, buruh dan penjual bensin eceran. Mayoritas profesi tersebut pendapatannya bersifat harian, sehingga jika mereka tidak bekerja berarti tidak memperoleh pendapatan.

\section{Dampak Pandemi Terhadap Pendapatan Masyarakat}

Walaupun pandemic mengakibatkan ada masyarakat kehilangan pekerjaan, dirumahkan, berpindah pekerjaan, jam kerja dibatasi, dan upah yang diturunkan, namun di sisi lain juga menimbulkan peluang kerja baru, misalnya penjual masker kain, penjahit-penjahit APD, penjual handsanitizer, penjual sabun cuci tangan serta pengadaan alat-alat kesehatan.Produkproduk herbal seperti jamu juga mengalami peningkatan permintaan di masa pandemic karena diyakini dapat meningkatkan daya tahan tubuh. Pandemi COVID-19 ini dapat memunculkan peluang kerja baru yang mengandalkan kreatifitas contohnya ada bisnis Frozen Food (Makanan Beku) yaitu makanan setengah jadi yang tinggal digoreng. Selain itu penggunaan media sosial serta aplikasi turut berkembang pesat di masa pandemic karena banyak transaksi penjualan yang dilakukan secara daring.

Menurut Camat Kubung selama pandemi ini, pusat pusat ekonomi di Solok seperti di mengalami penutupan sehingga perekonomian mengendur dan berefek terhadap Pemutusan Hubungan Kerja (PHK) besar-besaran bagi pelaku ekonomi yang ada di kawasan tersebut seperti di bisnis warung kopi, perhotelan dan jasa konveksi . Inovasi menjadi penting dengan adanya covid-19 ini apabila disiasati dengan baik oleh pelaku usaha yang terpapar dampak dari covid-19 ini dari segi ekonomi dengan beralih usaha ke bidang kesehatan dalam pembuatan APD dan masker bahkan pembuatan handsanitizer, sehingga dapat membuat dan membuka peluang usaha baru di masa pandemi ini. Pandemi menyebabkan masyarakat semakin kreatif dalam mencari peluang untuk menambah pendapatan.

Selama masa pandemic ini kegiatan perdagangan mengalami perbedaan yang sangat jelas, banyak usaha yang terpaksa harus tutup karena mengalami kerugian, omset penjualan yang jauh menurun, sehingga ada yang cara penjualannya juga berubah menjadi online 
misalnya semula berjualan donat dipinggir jalan sekarang karena tidak boleh berjualan jadi dia memilih menjual donatnya lewat online saja. Selama pandemic ini juga membuka peluang pekerjaan baru yaitu menjadi penjual masker dan pembuat masker. Ada warga yang awalnya tukang jahit khusus permak baju mengalami sepi permintaan permak, padahal biasanya sebelum pandemic pesanan untuk permak jahitan tidak pernah putus bahkan harus antri. Menurutnya, di awal pandemic orang menjadi takut keluar rumah, jika tidak terlalu penting. Akibatnya permintaan permak jahitan juga turun $80 \%$, parahnya lagi jahitan yang sudah selesai dipermak tidak pernah diambil konsumennya selama masa pandemic. Akhirnya untuk mengatasi sepinya permintaan permak jahitan, akhirnya dia banting setir menjahit masker namun hanya berdasarkan pesanan . Menurutnya walau hasilnya tidak sebesar permak jahitan namun masih bisa menambah pendapatan keluarga. Apalagi suaminya tidak bekerja, di masa pandemic ini akhirnya suaminya mau turut membantu menjual hasil kebun walaupun tidak banyak.

Harus diakui semenjak pandemi Covid diumumkan secara resmi oleh pemerintah Indonesia, dan terjadi pembatasan sosial serta masyarakat mengurangi aktivitas di luar rumah jika tidak perlu, maka dampaknya juga berpengaruh terhadap konsumen yang melakukan transasksi. Ada yang omzet penjualannya turun sampai 50\%. Banyak usaha kecil terdampak karena berkurangnya jumlah konsumen Mereka melakukan beberapa strategi agar penjulannya bertahan. Hal ini diperparah lagi dengan kenaikan harga bahan baku. Seorang penjual nasi goreng , selama pandemi COVID-19 ini mengurangi sepertiga belanja bahan baku nya seperti sawi dan beras .Namun sebisa mungkin responden ini tetap menyisihkan uang hasil pendapatannya untuk ditabung walau hanya 5.000-10.000/hari, dimana tabungan itu merupakan hasil tabungan dari pendapatan istri dan responden. Tabungan yang ada diperuntukkan untuk mempersiapkan masa depan seperti sekolah anak, berjaga- jaga ataupun hal-hal lainnya. Selain menyisihkan uangnya, responden ternyata sudah memiliki tabungan dimana tabungan tersebut difokuskan untuk memenuhi kebutuhan yang penting seperti membiayai kuliah anak yang berada diluar pulau, untuk berjaga-jaga ketika sakit, dan tidak digunakan untuk usaha. Tabungan ini cukup untuk memenuhi kebutuhan keluarga hingga saat ini.

Berdasarkan hasil wawancara terhadap penjual gorengan, dampak yang dirasakan terhadap pendapatannya adalah berkurangnya daya beli masyarakat. Sebelum pandemi COVID19 responden ini bisa memperoleh penghasilan bersih dari berjualan gorengan sebesar 300.000 - 400.000/hari sekarang hanya bisa memperoleh pendapatan bersih sebesar 60.000/hari . Kemudian dampak lain selama pandemi COVID-19 ini adalah pengurangan bahan baku yang digunakan, dari yang sebelumnya bisa menggoreng sebanyak 3-4 kg kentang, ubi, dan bengkoang sudah sangat sulit untuk terpenuhi sehingga sekarang hanya menjadi $1-1,5 \mathrm{~kg}$. Ssebelumnya menggunakan karyawan sebanyak 11 orang sekarang hanya tinggal 4 orang dan menggunakan keluarga. Untuk sementara responden ini belum bisa menabung di masa pandemi karena pendapatan hasil jualan hanya disisihkan untuk digunakan sebagai modal lagi untuk berjualan keesokan harinya. Prinsipnya jangan sampai kegiatan penjualan berhenti.

Tidak hanya pedagang kecil, usaha katering juga terdampak pandemic ini. Seoran responden pemilik usaha katering mengatakan usahanya berhenti total selama masa pandemic berlagsung karena seluruh kegiatan seperti arisan begitu juga acara pernikahan batal.Konsumen yang sudah membayar uang muka minta dikembalikan uang dan ini sangat memberatkab karena sudah terlanjur membeli bahan baku. Dampak yang sangat merugikan adalah ketika seluruh bahan baku untuk katering yang sudah jadi dan penuh di freezer ternyata tidak laku ketika dijual kembali. Tapi karena bahan semua sudah dalam bentu beku maka masih ada kesempatan untuk menjual barang tersebut secara on line dengan waktu yang lebih panjang. Beberapa karyawan harian yang bekerja di katering ini juga mendadak kehilangan pekerjaan dan mencari pekerjaan lain. Pendapatan usaha ini turun sekitar $70 \%$ karena selama pandemic memang tidak ada pesanan. Responden beralih menjadi reseller ikan kering yang 
dijual secara daring dan mendapatkan pengganti pendapatan dari usaha baru tersebut walau tidak sebesar usaha katering.

Pandemi ternyata juga memberikan dampak terhadap profesi dadakan, yaitu penjual masker. Seorang penjual masker mengatakan bisa memperoleh $700.000-1.000 .000$ dalam sehari bahkan bisa lebih pada awal-awal penyebaran COVID-19 Untuk keuntungan bersihnya bisa memperoleh $40-50 \%$ dari penghasilan hari itu. Berdasarkan keterangannya, responden ini menjual masker memang karena pada saat COVID-19 ini saja, sebelumnya ia menjual pakain dan pada saat pandemic pendapatan dari penjulan pakaian menurun sehingga ia beralih menjual masker juga sambil berjualan pakaian ditambah dengan penjualan lain seperti kacamata, sarung tangan, jas hujan. Penjualan masker ini diperoleh dengan mengambil dari agen masker di Pasar.

Bagaimana dengan pendapatan penjual koran di masa pandemi? Apakah penjualan koran terkena imbas juga? Berdasarkan hasil wawancara kepada responden penjual koran selama pandemi COVID-19 ini penjualan koran juga menurun, hal ini dikarenakan sebagian besar orang tidak melakukan aktivitas diluar rumah dan banyak warung kopi yang menutup usahanya sehingga tidak bisa mampir untuk berjualan di tempat tersebut. Diceritakan, sebelum pandemi sehari-hari responden bisa memperoleh pendapatan bersih sekitar $60.000-70.000$ dalam sehari dengan penjualan mencapai 100-120 koran dalam sehari dan sekarang saat pandemi ini penjualannya jadi menurun dan biasanya memperoleh pendapatan bersih mencapai 40.000 - 45.000. Selama pandemi, ia memutuskan untuk mengurangi jumlah pengambilan koran yang diambil dari agen . Menuerut responden selama pandemi ini, pendapatan yang ada masih cukup untuk menghidupi kebutuhan sehari-hari. Untuk menambah pendapatan , responden ini memanfaatkan keahliannya dalam memperbaiki listrik dirumah warga sekitarnya, memperbaiki peralon, bertukang, mengangkut pasir, dan kerja serabutan lainnya. Responden juga terbantu karena istrinya bekerja sebagai pemulung sehingga menambah pendapatan keluarga.

Penjual bensin juga terkena dampak pandemic ini. Sebelum pandemi COVID-19 ini melanda sehari-hari responden membuka usaha berjualan bensin eceran dari jam 04.00 s.d 18.00 bisa menjual bensin sebanyak 60 liter/hari dengan penghasilan bersih mencapai 48.000 sedangkan selama COVID-19 melanda terjadi penurunan omzet penjualan mencapai 50\% dari biasanya, dimana ia hanya dapat menjual bensin sebanyak 30-32 liter/hari dengan penghasilan bersih sebesar 24.000. Sistem penjualan yang dilakukan responden adalah dengan memperoleh bensin dari agen dengan harga modal sebesar 7.200 dengan menetapkan harga jual sebesar 8.000/liter. Penjual bensin ini juga mengerjakan pekerjaan lain yaitu bekerja sambilan sebagai tukang parkir dengan penghasilan sebesar 20.000 s.d 30.000/hari mengingat lokasi tempatnya berjualan bensin dekat dengan took jamu.

Di masa pandemi, mulai diberlakukan bekerja dari rumah untuk jenis pekerjaan tertentu, demikian juga belajar dari rumah untuk para pelajar dan mahasiswa, bahkan berbelanja pun akhirnya dari rumah. Hal ini menimbulkan kebutuhan baru yaitu meningkatnya permintaan kuota internet. Bagaimana dampaknya bagi penjual jasa kuota/pulsa di masa pandemic di Solok? Salah seorang responden mengatakan omset yang didapat turun sekitar 1015 persen, awalnya di kisaran Rp.4.000.000/hari menjadi Rp.3.700.000-an/hari dan belum untung bersih. Diakuinya bahwa kebanyakan pelanggan responden berasal dari mahasiswa sehingga hal ini menjadi penyebab penurunan pendapatan usahanya dikarenakan banyak mahasiswa pulang kampung sehingga pembeli berkurang. Hal ini karena di lokasi kios responden banyak rumah kos dan kontrakan mahasiswa luar daerah Solok. Untuk mendapatkan tambahan pendapatan, responden membuka pula jasa service telepon selular dan bayar token listrik serta pembayaran PDAM. Pekerjaan sebagai buruh cuci dan aisten rumah tangga di rumah orang lain ternyata tidak terpengaruh pandemic. Mereka tetap menerima gaji per bulan dari majikannya. Namun, menurut responden ini beban pengeluaran rumah tangga justru menjadi lebih berat karena suaminya dirumahkan akibat toko mebel tempatnya bekerja lockdown dan seluruh pekerja dipulangkan ke daerah masing-masing. Akibatnya responden yang menanggung seluruh kebutuhan keluarga. 
Pendapatan responden lain yang bekerja sebagai buruh bangunan juga terpengaruh selama pandemic dikarenakan selama pandemic proyek terhenti. Jadi bisa dibilang pendapatannya berkurang sebanyak $80 \%$ sehingga responden mencari sumber pendapatan lain dengan menjual layangan ataupun menjual ikan cupang. Pekerjaan itupun bertahan selama 1,5 bulan. Responden ini memiliki sedikit tabungan dari hasil bekerja sebagai buruh bangunan dan dapat bertahan hanya sebulan. Untungnya responden tidak memiliki cicilan maupun hutang. Untuk memenuhi kebutuhannya didapat dari orangtuanya dan mertuanya karena ia tinggal di tempat mertuanya. Responden lain yang bekerja sebagai buruh bangunan juga mengalami hal yang sama, namun ia masih memiliki tabungan dan punya emas untuk digadaikan sehingga masih bis untuk menutupi pengeluaran keluarga kecilnya. Sejak adanya wabah covid 19 ini pendapatan sebagai pemilik salon kecil jelas sangat menurun karena pengunjung salon sepi dan responden mengalami penurunan pendapatan salon sekitar $70 \%$. Untuk memenuhi kebutuhan sehari-hari responden mengandalkan tabungan dan pendapatan suami.

Beberapa teman satu profesi dengan responden bahkan terpaksa harus menutup salonnya dan menjual barang-barang salon untuk mendapatkan uang selama masa pandemic ini. Responden selama masa pandemic ini terpaksa harus merumahkan karyawannya sehingga responden sendiri yang turun tangan dalam melayani pelanggan. Bagaimana dampak pandemic terhadap bidang transportasi? Seoang pekerja ojek online sudah satu bulan tidak bekerja sejak awal pandemic karena terbatasnya orang yang menguunakan transportasi on line selama pandemic sehingga pendapatannya turun hingga $80 \%$. Responden ininjuga mengandalkan tabungan selama tidak bekerja. Sebulan setelah itu akhirnya dia memutuskan bekerja kembali namun konsumen sangat sedikit. Responden lainnya adalah supir oplet trayek luar kota yang juga mengalami penurunan pendapatan karena banyak orang yang dari desa tidak berani ke kota sejak adanya covid 19. Sebelum masa pandemic pendapatan nya bisa mencapai Rp.100.000, sekarang menjadi Rp. 40.000 saja. Untuk memenuhi kebutuhan sehari-hari ia berhemat dengan uang yang ada saja, responden ini dibantu oleh istrinya yang mulai bekerja untuk menerima jasa cuci pakaian. Responden ini berkata tidak memiliki pilihan selain tetap menjadi supir oplet selama pandemic ini meskipun sepi karena susah mencari kerja apalagi disaat seperti ini. Responden lain yang bekerja sebagai sebagai supir ekdpedisi luar kota juga pendapatannya turun karena frekwensi kerjanya berkurang drastis dari 7 hari seminggu menjadi hanya satu hari seminggu. Responden tertolong karena anaknya ada yang telah bekerja dan bisa membantu dalam memenuhi kebutuhan hidup sehari-hari selama pandemi berlangsung. Setidaknya tidak harus berhutang kepada pihak manapun.

Bagaimana dengan pendapatan juru parkir? Pendapatan responden juru parkir di pasar selama masa pandemic ini turut berkurang dikarenakan masyarakat yang berbelanja ke pasar juga tidak ramai. Masyarakat mengurangi frekwensi belanja di pasar selama pandemic, yang semula tiap hari menjadi seminggu sekali belanja di pasar. Sebagian masyarakat kadang lebih memilih berbelanja di warung dibandingkan pasar untuk menghindari keramaian. Ini menyebabkan pendapatan sebagai juru parkir berkurang drastis. Untuk mengatasi pengeluaran keluarga responden berhutang kepada koperasi. Responden masih tertolong karena istrinya bekerja di warung kopi sehingga dapat menambah pendapatan keluarga

\section{Pola Perilaku Konsumsi}

Secara umum memang terjadi penurunan tingkat pendapatan responden selama masa pandemic, namun tidak semua responden melakukan perubahan pola pangan secara drastis. Terdapat perbedaan pola pegeluaran responden sebelum dan saat masa pandemic. Responden melakukan beberapa penyesuaian sesuai kebutuhan atau menghilangkan beberapa jenis pengeluaran keluarga yang masih memungkinkan. Bersiasat di saat sulit itulah yang mereka lakukan. Untuk pola pangan tidak terdapat perubahan drastis seperti mengganti makanan pokok nasi dengan sumber karbohidrat lain. Mereka hanya mengganti jenis lauk tertentu dan lebih memilih mencari sumber pendapatan lain untuk mempertahankan pola pengeluaran yang lama daripada merubah pola pengeluaran keluarga. Penghematan lainnya yang dilakukan 
dengan membawa bekal untuk mengurangi pengeluaran makan siang dikarenakan sebelumnya membeli makan siang di warung.. Membeli pulsa per bulan menjadi lebih berhemat hanya untuk yang penting-penting saja. Beberapa responden mengurangi pengeluaran untuk membeli rokok serta melakukan penghematan. Ada juga responden yang mencari tambahan lauk dengan memancing ikan di sungai. Meskipun pengeluaran untuk konsum si makanan berkurang hingga 40\% namun responden tetap makan seperti biasa, dan hanya menyesuaikan lauk dengan pendapatan yang diperoleh.. Ada juga responden yang mendapat bantuan pemerintah berupa beras. Selama pandemi ini, responden mendapat bantuan beras dari pemerintah sebanyak $60 \mathrm{Kg}$ dengan rincian $20 \mathrm{Kg}$ dari Pemkot, $20 \mathrm{Kg}$ dari Pemprov dan $20 \mathrm{Kg}$ dari Kelurahan.

Pengeluaran untuk biaya listrik dan air tidak berubah drastis, mereka tertolong dengan subsidi listrik yang diberikan pemerintah terutama pelanggan golongan 450 watt. Namun kebanyakan responden menggunakan daya listrik 950 watt yang tidak bersubsidi, karena daya 450 watt sangat terbatas kapasitas penggunaannya untuk saat ini. Untuk penggunaan air ternyata tidak semua responden menggunakan air produksi PDAM. Kebanayakan responden menggunakan sumber air hujan, sumur bor serta air parit/sungai untuk kebutuhan rumah tangga. Air minum biasanya mereka membeli air isi ulang yang murah. PDAM di masa pandemic memang ada memberi potongan 50\% untuk pelanggan berpenghasilan rendah serta pelanggan sosial seperti rumah ibadah, yayasan, sekolah atau panti selama tiga bulan. sehingga cukup meringankan konsumen. Dalam kalkulasi PDAM , setidaknya ada 113 ribu dari 129 ribu pelanggan atau 80 persen warga Solok yang menikmati program gratis tagihan PDAM ini. Beberapa hal berikut dilakukan responden dalam melakukan strategi pengeluaran.

Pemerintah mengeluarkan kebijakan di masa pandemic dengan menggratiskan biaya langganan listrik selama 4 bulan untuk rumah tangga pengguna golongan daya $450 \mathrm{VA}$. Hal ini sangat meringankan beberapa responden, namun sebagian besar responden golongan daya listriknya adalah 950 VA yang tidak mendapat subsidi. Secara umum tidak terdapat kenaikan biaya listrik di masa pandemic karena penggunaan secara normal.Pengeluaran untuk air bersih PDAM juga tidak mengalami perubahan. Responden hanya mensiasati dengan menggunakan air hujan untuk sumber air minum dan mandi serta untuk kebutuhan rumah tangga.

Secara umum responden mengakui bahwa di masa pandemic mereka tetap makan seperti biasa, hanya mengganti jenis lauk tertentu. Ada juga yang bersiasat membeli bahan lauk di saat harga murah dengan jumlah yang banyak dan disimpan dikulkas. Selama pandemic covid ini responden memang berhemat dengan belanja ditempat yang lebih murah. Jenis lauk yang sring dimakan yaitu ikan sayur dan sambal jika sedang tidak memiliki uang maka hanya memasak mie atau menggoreng telur saja. Pada awalnya beberapa responden responden merokok tetapi karena sejak adanya covid mereka memilih untuk berhenti merokok agar uang membeli rokok tersebut bisa untuk menambah biaya rumah tangga. Akan tetapi beberapa responden lainnya memiilih untuk tetap merokok dan hanya mengurangi jumlah rokoknya. Ada juga responden yang tidak mengurangi kebiasaan merokoknya dan tetap merokok seperti biasa, hanya saja beralih ke rokok yang haraganya jauh lebih murah. Bagi respoden perokok berat, mereka lebih memilih berganti merek rokok daripada menghentikan kebiasaan merokok karena menurut mereka itu sulit. Ada juga responden yang mendapat rokok dari meminta kepada sesame teman perokok. Pengeluaran yang mereka kurangi juga adalah uang jajan anak. Kebetulan anak juga tidak ke sekolah sehingga bisa menghemat pengeluaran jajan.

\section{Penutup}

Pendapatan responden mengalami penurunan tajam antara $30 \%-70 \%$ di awal masa pandemic sementara pengeluaran cenderung tetap. Kondisi ini menyebabkan mereka harus mensiasati pengeluaran keluarga. Secara umum memang terjadi penurunan tingkat pendapatan responden selama masa pandemic, namun tidak semua responden melakukan perubahan pola pangan secara drastis. Mereka hanya mengganti jenis lauk tertentu dan lebih memilih mencari sumber pendapatan lain untuk mempertahankan pola pengeluaran yang lama daripada merubah pola pengeluaran keluarga. Beberapa responden mengurangi pengeluaran 
untuk membeli rokok serta melakukan penghematan. Ada juga responden yang mencari tambahan lauk dengan memancing ikan di sungai. Meskipun pengeluaran untuk konsumsi makanan berkurang hingga $40 \%$ namun responden tetap makan seperti biasa, dan hanya menyesuaikan lauk dengan pendapatan yang diperoleh. Pengeluaran untuk biaya listrik dan air tidak berubah drastis, mereka tertolong dengan subsidi listrik yang diberikan pemerintah. Kebanyakan responden mengandalkan air hujan, sumur bor dan air parit. Tokoh masyarakat di tingkat RT dapat menjadi tokoh sentral pemersatu yang dapat merangkul warganya yang mampu untuk membantu masyarakat di lingkungannya sendiri yang terdampak pandemic covid-19. Mereka dapat saling berkontribusi dalam gerakan amal bakti sosial tingkat RT.

\section{Daftar Pustaka}

Ahmadi, M., Sharifi, A., Dorosti, S., Jafarzadeh Ghoushchi, S., \& Ghanbari, N. (2020). Investigation of effective climatology parameters on COVID-19 outbreak in Iran. Science of the Total Environment, 729. https://doi.org/10.1016/j.scitotenv.2020.138705.

Ahmed, F., Ahmed, N., Pissarides, C., \& Stiglitz, J. (2020). Why inequality could spread COVID-19. The Lancet Public Health, 5(5), e240. https://doi.org/10.1016/S24682667(20)30085-2.

Badan Pusat Statistik (BPS). (2020). Makro Ekonomi Solok.

Cartenì, A., Di Francesco, L., \& Martino, M. (2020). How mobility habits influenced the spread of the COVID-19 pandemic: Results from the Italian case study. Science of the Total Environment. https://doi.org/10.1016/j.scitotenv.2020.140489.

Ercelawn, A. A. (1990) Absolute Poverty in Pakistan: Poverty Lines, Incidence, Intensity. Applied.

Economics Research Centre, University of Karachi, Karachi.

Flores, M. F. (2019). Understanding The Challenges of Remote Working and It's Impact To Workers, 4(11), 40-44.

McKibbin, W. J., \& Fernando, R. (2020). The Global Macroeconomic Impacts of COVID-19: Seven

Scenarios. SSRN Electronic Journal. https://doi.org/10.2139/ssrn.3547729.

Patel, J. A., Nielsen, F. B. H., Badiani, A. A., Assi, S., Unadkat, V. A., Patel, B., Wardle, H. (2020).

Poverty, inequality and COVID-19: the forgotten vulnerable. Public Health, 183, 110-111. https://doi.org/10.1016/j.puhe.2020.05.006.

Rocklöv, J., \& Sjödin, H. (2020). High population densities catalyse the spread of COVID-19.

Journal of Travel Medicine, 27(3), 1-2.

Setyawan, F. E. B., \& Lestari, R. (2020). Challenges of Stay-At-Home Policy Implementation During The Coronavirus (Covid-19) Pandemic In Indonesia. Jurnal Administrasi Kesehatan.

World Bank. (2020). East Asia and Pacific in the Time of Covid-19. World Bank East Asia and Pacific Economic Update. https://doi.org/10.1596/978-1-4648-1565-2. 